\title{
KONCEPCJA ARCHITEKTONICZNA FUNKCJONALNO-PRZESTRZENNA INNOWACYJNEGO CENTRUM NAUK ŻYWIENIOWYCH SGGW
}

\author{
Piotr Fornalczyk ${ }^{凶}$ \\ Instytut Inżynierii Lądowej, Szkoła Główna Gospodarstwa Wiejskiego w Warszawie
}

\begin{abstract}
STRESZCZENIE
Potrzeba usprawnienia i rozwoju bazy dydaktycznej i naukowej w zakresie nauk żywieniowych jest jednym z priorytetów Unii Europejskiej i Polski. W artykule przedstawiono genezę powstania, podstawy formalnoprawne oraz główne założenia funkcjonalno-przestrzenne oraz materiałowo-konstrukcyjne koncepcji architektonicznej Innowacyjnego Centrum Nauk Żywieniowych SGGW, które wpisuje się w trendy rozwojowe tej dziedziny na świecie.
\end{abstract}

Słowa kluczowe: projekt, innowacja, nauka, żywienie

\section{WSTĘP}

Dbałość o zdrowe odżywianie i zapewnienie wysokiej jakości produktów spożywczych stanowi obecnie istotne wyzwanie zarówno dla producentów żywności, jak i naukowców. Przedmiotem dyskusji i badań naukowych są coraz częściej zagadnienia dotyczące zdrowej diety, zrównoważonego gospodarowania żywnością, bezpieczeństwa żywności, innowacyjnych rozwiązań w produkcji żywności, technologii konserwowania i wprowadzania nowych składników do żywności, jak również chorób cywilizacyjnych związanych z odżywianiem. Lewis i Burton-Freeman (2010) oraz Boratyńska i Huseynov (2017) podkreślają, że patogeny przenoszone na żywności pozostają poważnym problemem zarówno w krajach rozwiniętych, jak i rozwijających się, powodując ludzkie cierpienia i znaczne straty ekonomiczne. Ponadto co roku na jedną trzecią populacji krajów rozwiniętych mogą wpływać choroby rozprzestrzenione przez konsumpcję zainfekowanej żywności, a problem ten jest jeszcze bardziej rozpowszechniony w krajach rozwi- jających się. Glover i Poole (2019) podają, że w celu osiągnięcia zrównoważonego rozwoju ukierunkowanego przede wszystkim na bezpieczeństwo żywności i żywienia w wielu krajach świata istnieje potrzeba innowacji, która ma szczególne znaczenie w produkcji, przetwarzaniu i dystrybucji żywności. Savino, Testa i Messeni Petruzzelli (2018) wskazują, że obecnie badania naukowe podzieliły Europę na dwa główne regiony makrokulturowe (kraje skandynawskie i południowoeuropejskie), prezentujące określone wzorce konsumpcji żywności, oraz że można wyszczególnić kilka kierunków w badaniach nad innowacyjnością w naukach o żywieniu: inicjatywy polityki innowacyjnej, sieci innowacji, innowacje w tradycyjnych produktach żywnościowych oraz alternatywne systemy żywności.

Działalność naukowa w zakresie żywienia powinna bezpośrednio łączyć się z aspektami wdrożeniowymi i edukacyjnymi, co w szczególności jest możliwe do realizacji poprzez sukcesywną rozbudowę infrastruktury wiedzy w zakresie nauk o żywieniu i sprowadza się do konieczności budowy lub rozbudowy 
Fornalczyk, P. (2019). Koncepcja architektoniczna funkcjonalno-przestrzenna Innowacyjnego Centrum Nauk Żywieniowych SGGW. Acta Sci. Pol. Architectura, 18 (4), 95-103. doi: 10.22630/ASPA.2019.18.4.49

bądź modernizacji krajowych centrów bezpieczeństwa i technologii żywności oraz edukacji żywieniowej, mając na uwadze priorytet innowacyjności. Niemniej jednak Shilomboleni i De Plaen (2019) wskazują, że przeniesienie innowacji $\mathrm{z}$ laboratorium badawczego do praktyki wymaga współpracy i interakcji między wieloma podmiotami: badaczami, urzędnikami, przedstawicielami sektora prywatnego i grupami społeczeństwa obywatelskiego.

Obecnie, z uwagi na skalę i aktualność tematyki zdrowej żywności i żywienia człowieka, wiele ośrodków naukowych na całym świecie podejmuje badania w tym zakresie. Do największych i najbardziej znanych można zaliczyć: Centrum Żywienia Gretchen Swanson (The Gretchen Swanson Center for Nutrition) w Stanach Zjednoczonych, Centrum Innowacji Żywienia i Zdrowia (Nutrition Innovation Centre for Food and Health - NICHE) w Irlandii, Centrum Zdrowego Żywienia i Innowacji Żywności (Centre for Healthy Eating and Food Innovation - HEFI) w Holandii czy Centrum Nauk o Żywieniu i Żywności (Centre for Nutrition and Food Sciences - CNAFS) w Australii.

$\mathrm{W}$ trend realizacji zaawansowanych badań na skalę międzynarodową wpisywać się będzie Innowacyjne Centrum Nauk Żywieniowych SGGW, podejmując holistyczne podejście do badań nad żywnościa i żywieniem człowieka oraz ich wdrożeniowy charakter.
Dziewiątego sierpnia 2018 roku między SGGW - reprezentowaną przez Rektora SGGW prof. dr. hab. Wiesława Bielawskiego - oraz Ministerstwem Nauki i Szkolnictwa Wyższego - reprezentowanym przez Wiceprezesa Rady Ministrów, Ministra Nauki i Szkolnictwa Wyższego Jarosława Gowina - podpisana została umowa dotycząca finansowania projektu o nazwie Innowacyjne Centrum Nauk Żywieniowych SGGW (rys. 1). Wartość projektu została wyceniona wstępnie na 62 miliony złotych, z czego 40 milionów wyniesie dofinansowanie $z$ budżetu Ministerstwa Nauki i Szkolnictwa Wyższego. Idea projektu centrum oraz jego program funkcjonalny opracowane zostały przez zespół pracowników naukowych Wydziału Nauk o Żywieniu Człowieka i Konsumpcji SGGW pod kierunkiem prof. dr hab. Krystyny Gutkowskiej - Dziekana tego wydziału. Celem powstania ICNŻ SGGW jest prowadzenie szeroko pojętej działalności naukowej w zakresie nauk o żywieniu człowieka oraz promowanie powiązanych $\mathrm{z}$ nimi działań wdrożeniowych i edukacyjnych. $\mathrm{Z}$ założenia obiekt ma być budynkiem ze wszech miar nowoczesnym, wyposażonym w unikatowa aparature laboratoryjna i wykorzystującym najnowsze technologie. Prowadzone tu w przyszłości badania oraz powiązana z nimi działalność dydaktyczna mają być na najwyższym światowym poziomie i maja zapewnić wzrost znaczenia nauki polskiej w skali międzynarodowej.

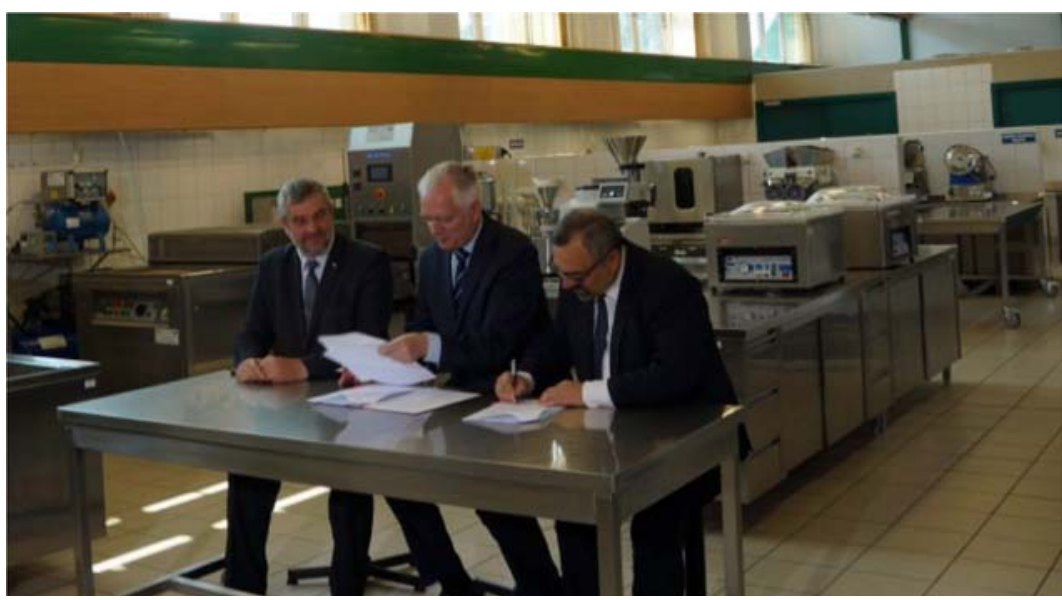

Rys. 1. Podpisanie umowy o finansowaniu inwestycji (https://www.sggw.pl/image/cache/data/SGGW/MULTI-UPLOAD /2018/08/09/Premier_6_1200-620x500o.jpg)

Fig. 1. Signing the investment financing agreement (https://www.sggw.pl/image/cache/data/SGGW/MULTI-UPLOAD /2018/08/09/Premier_6_1200-620x500o.jpg) 
Fornalczyk, P. (2019). Koncepcja architektoniczna funkcjonalno-przestrzenna Innowacyjnego Centrum Nauk Żywieniowych SGGW. Acta Sci. Pol. Architectura, 18 (4), 95-103. doi: 10.22630/ASPA.2019.18.4.49

$\mathrm{Na}$ zlecenie władz SGGW na przełomie 2018 i 2019 roku opracowany został przez autora artykułu „Projekt koncepcyjny Innowacyjnego Centrum Nauk Żywieniowych SGGW". Stanowić ma on podstawę do opracowywania dalszych etapów wielobranżowej dokumentacji projektowej (projektu budowlanego oraz projektów wykonawczych) oraz późniejszej realizacji obiektu. Projekt ukierunkowany był na zapewnienie funkcjonalności obiektu, a przede wszystkim na podejmowanie działalności badawczej i dydaktycznej na światowym poziomie.

Główne podstawy formalnoprawne do opracowania projektu koncepcyjnego INCŻ SGGW stanowiły:

- umowa na udzielenie dotacji przez Ministerstwo Nauki i Szkolnictwa Wyższego,

- program funkcjonalno-metrażowy ICNŻ SGGW opracowany przez przyszłego użytkownika - Wydział Nauk o Żywieniu Człowieka i Konsumpcji SGGW - uwarunkowania wynikające ze „Studium uwarunkowań i kierunków zagospodarowania przestrzennego m.st. Warszawy" przyjętego uchwałą nr LXXXII/2746/2006 Rady m.st. Warszawy,

- „Dokumentacja badań podłoża ICNŻ SGGW w Warszawie" opracowana w Katedrze Geoinżynierii SGGW,

- mapa numeryczna obejmująca teren kampusu SGGW,

- obowiązujące normy i przepisy oraz wiedza techniczna i architektoniczna $\mathrm{w}$ aspekcie dostosowania projektowanego centrum do istniejącej zabudowy na terenie kampusu SGGW.

\section{UWARUNKOWANIA LOKALIZACYJNE}

Teren o powierzchni ok. 1,5 ha jest częścią kampusu przy ulicy Nowoursynowskiej 159 w Warszawie i stanowi własność SGGW z przeznaczeniem na inwestycje służące celom badawczo-dydaktycznym. Teren znajduje się między aleją Rodowicza „Anody” od strony zachodniej a budynkiem Wydziału Ogrodnictwa i Biotechnologii oraz Rolnictwa i Biologii (37) od strony wschodniej. Część działki obejmuje naziemny parking dla samochodów osobowych na 170 stanowisk postojowych, a resztę stanowi teren $\mathrm{z}$ roślinnością trawiastą. Od strony północnej znajduje się zespół domów akademickich i hoteli SGGW, a od południowej budynki i szklarnie Wydziału Ogrodnictwa i Biotechnologii.

Przedmiotowa lokalizacja sąsiaduje od strony zachodniej z wjazdem na teren SGGW z jezdni alei Rodowicza „Anody” i jest częścią wewnętrznej sieci komunikacji kampusu.

Obszar inwestycji jest terenem płaskim, bez zieleni wysokiej - oprócz szpaleru kilkuletnich lip rosnących wzdłuż granicy wspomnianego parkingu.

Nowy obiekt zlokalizowany zostanie przed istniejącym budynkiem 37 (oraz znajdującym się przed nim dużym parkingiem) - niejako w jego gabarycie. Projekt zakłada podział budynku na dwie, połączone górą części. Między nimi przebiega ciąg pieszo-jezdny, którego zadaniem jest dodatkowe skomunikowanie piesze oraz kołowe terenu centrum (dojścia, dostawy itp.). Wymiary poziome i pionowe (wysokość pod łącznikami $8,5 \mathrm{~m}$ ) gwarantują swobodny przejazd nawet dużych pojazdów (straż pożarna, samochody ciężarowe czy niewielki dźwig lub koparka w przypadku ewentualnej awarii). Lokalizację ICNŻ SGGW wraz $\mathrm{z}$ otoczeniem pokazano na rysunku 2 .

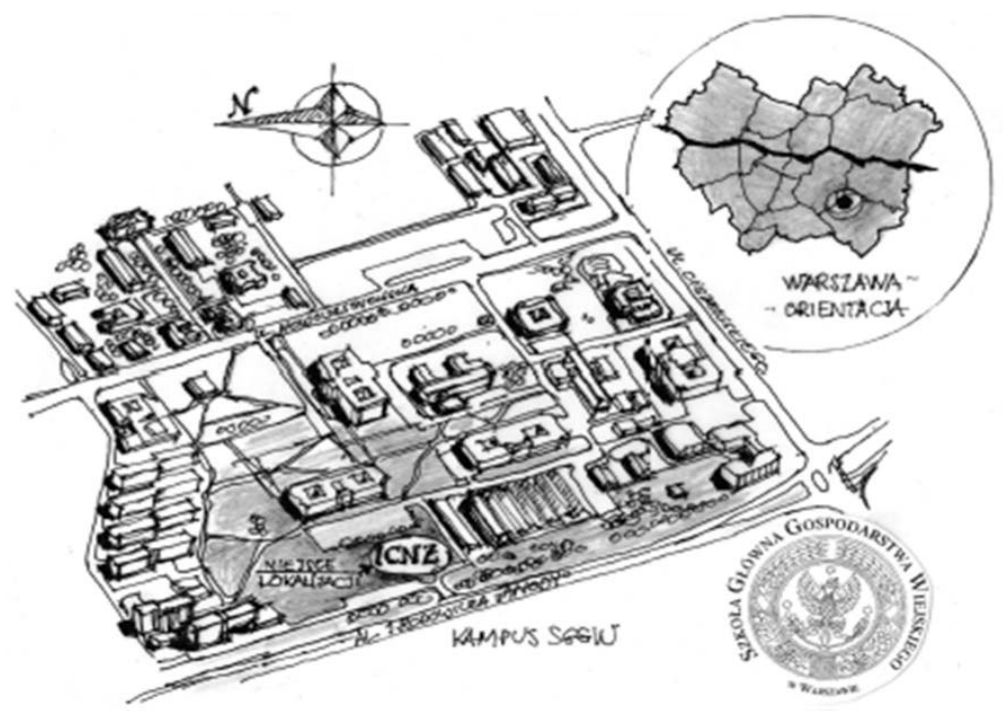

Rys. 2. Miejsce lokalizacji inwestycji (opracowanie własne)

Fig. 2. Place of investment location (own elaboration) 


\section{KSZTAŁT FUNKCJONALNO-PRZESTRZENNY OBIEKTU}

Przed przyjęciem założeń do koncepcji ICNŻ SGGW prowadzono szeroko pojętą akcję programową w zakresie działalności naukowo-badawczej oraz dydaktyczno-edukacyjnej. Projektowany budynek ma umożliwić przede wszystkim prowadzenie zaawansowanych badań naukowych żywności oraz realizację działalności dydaktycznej, a także organizowanie konferencji, sympozjów naukowych i wystaw.

\section{Kształt zewnętrzny}

Kubatura projektowanego centrum podzielona została na dwie części połączone łącznikami na wysokości drugiego i trzeciego piętra. Taki podział i ukształtowanie bryły umożliwiło uzyskanie:

- czytelnego układu funkcjonalnego,

- naturalnego doświetlenia pomieszczeń - szczególnie laboratoryjnych (o zróżnicowanej powierzchni),

- czytelnego wewnętrznego i zewnętrznego układu komunikacyjnego (dojścia, podjazdy, wejścia i wyjścia - także ewakuacyjne),

- rozrzeźbionej bryły o architekturze „nachylonej ku słońcu".

Obie czę́si centrum „rosną” schodkowo w kierunku północno-wschodnim, umożliwiając wykonywanie na części stropów niższych kondygnacji stropodachów biologicznie czynnych, które również mają spełniać cele badawcze dla innych jednostek uczelni. Jako że „otwierają się” one na południe i zachód, zarówno w cyklu dobowym, jak i rocznym zapewnione mają dobre nasłonecznienie. Bariery zewnętrzne stropodachów biologicznie czynnych od strony południowej i zachodniej zaprojektowano jako konstrukcje w formie trzymetrowych płaszczyzn, nachylonych pod kątem $45^{\circ}$, z myślą o zamontowaniu na nich ogniw fotowoltaicznych. Takich balustrad na wszystkich kondygnacjach obu części budynku jest ok. $280 \mathrm{mb}$, co przy ich szerokości $(3 \mathrm{~m})$ daje powierzchnię ok. $840 \mathrm{~m}^{2}$. Ogniwa takie mją być zamonotowane także pod oknami elewacji południowej - na specjalnie zaprojektowanych w tym celu geometrycznych konstrukcjach ze stali nierdzewnej. Zarówno opisane pochyłe płaszczyzny balustrad stropodachów, jak i wspomniane konstrukcje przyokienne umożliwiają dodatkowo prowadzenie w nich różnego rodzaju instalacji zewnętrznych. Umożliwiają też rozmieszczenie elementów zewnętrznego oświetlenia elewacji, które w ten sposób zyskają na atrakcyjności - szczególnie widziane od strony alei Rodowicza „Anody”. Widok elewacji przedstawiono na rysunkach 3 i 4.

Najniższy poziom stropodachów obu części budynku (stropodach nad parterem) planuje się wykonać w technologii stropodachu biologicznie czynnego, tak zwanego bagiennego - wykorzystywanego jako zbiornik na wody opadowe $\mathrm{z}$ budynku. W podobnym celu między obiema częściami budynku proponuje się wykonanie dwóch zbiorników naziemnych. Zaprojektowane $\mathrm{w}$ formie oczek wodnych o geometrycznych kształtach - oprócz zadania gromadzenia wód opadowych - dodatkowo uatrakcyjnią teren centrum. Ewentualne nadwyżki wód opadowych odprowadzane będą do istniejącej sieci kanalizacji deszczowej albo będa wykorzystane do nawadniania roślinności na terenie kampusu.

Pozostałe stropodachy proponuje się wykonać jako biologicznie czynne, pokryte roślinnością. Stopień ich intensywności i rodzaj nasadzeń zostaną określone szczegółowo na etapie sporządzania projektu budowlanego centrum. Zakłada się, że „zielone" powierzchnie stropodachów będą wykorzystywane przez przyszłych użytkowników także w celach rekreacyjnych. Jak wiadomo, stropodachy pokryte roślinnością (także bagienne i te będące zbiornikami wód opadowych) wliczane są do powierzchni biologicznie czynnych. Pozytywnie wpływają na mikroklimat, oczyszczają powietrze, pochłaniają dwutlenek węgla i produkują tlen, stanowią więc dodatkową izolację dla wnętrz - zarówno termiczną, jak i akustyczną. Wyniki mogą być wykorzystywane do prac dyplomowych i innych celów dydaktycznych i badawczych.

Od strony południowej zaprojektowano pochylone pod kątem $45^{\circ}$ konstrukcje do montażu na nich kolektorów słonecznych. Pokazane na rysunkach elewacji budynku (głównie elewacji południowej) umożliwiają uzyskanie powierzchni kolektorów na poziomie ok. $325 \mathrm{~m}^{2}$. Ciepło z nich uzyskane może zostać spożytkowane do celów grzewczych, podgrzania wody 


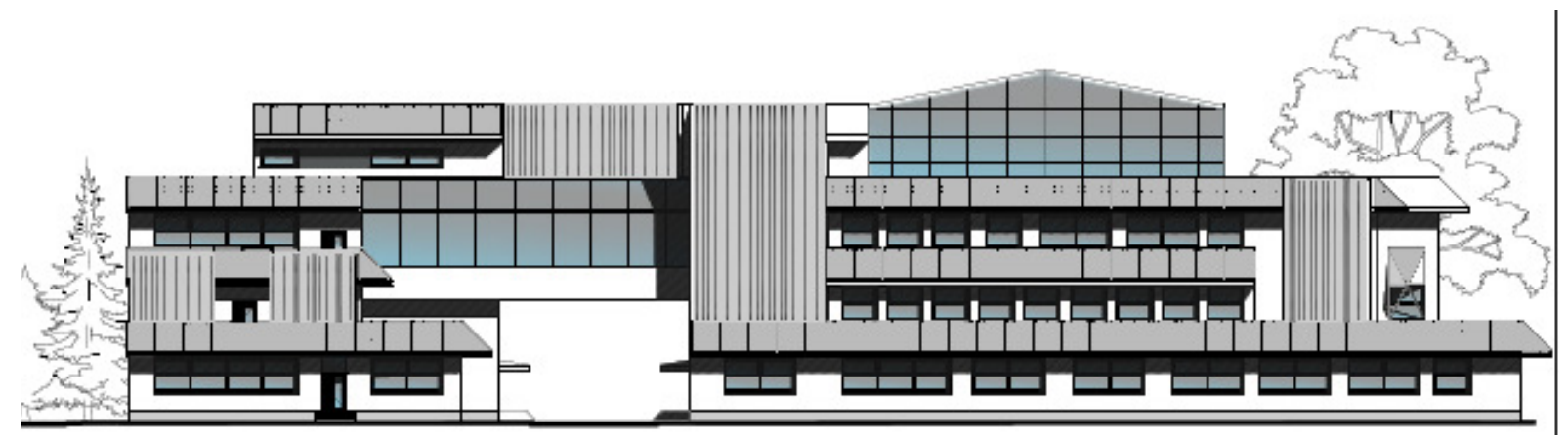

Rys. 3. Innowacyjne Centrum Nauk Żywieniowych SGGW - elewacja południowa (opracowanie własne)

Fig. 3. Innovative Centre for Nutritional Sciences WULS-SGGW - southern facade (own elaboration)

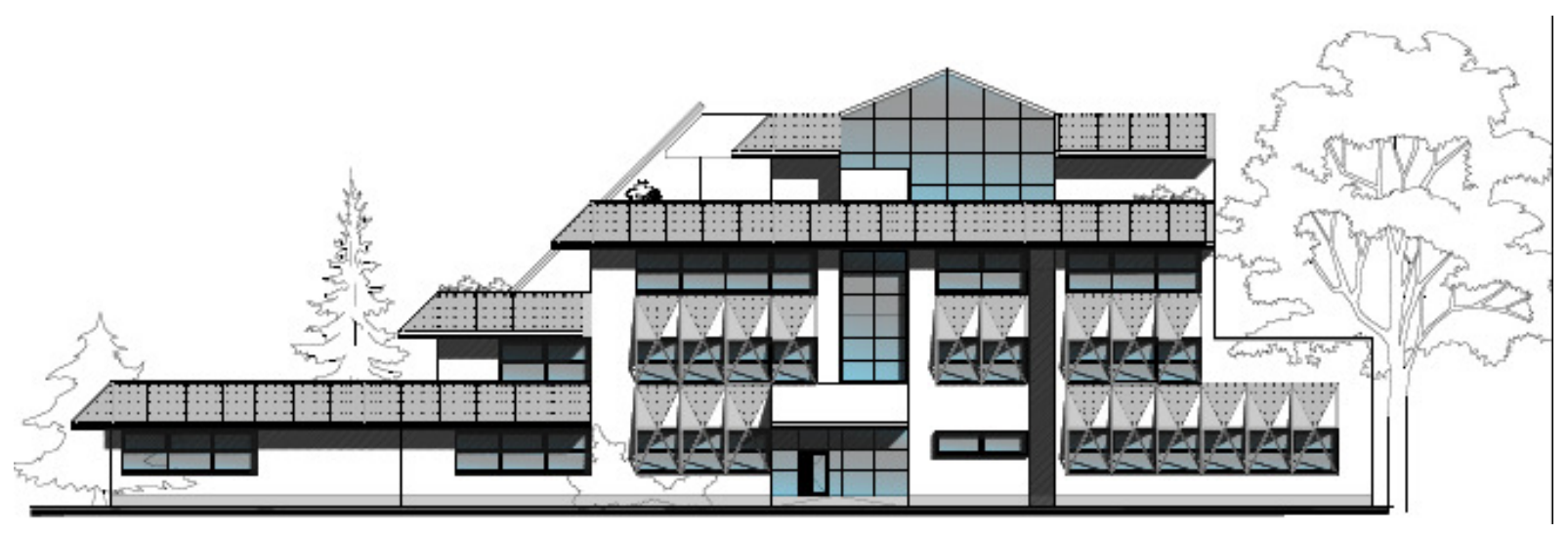

Rys. 4. Innowacyjne Centrum Nauk Żywieniowych SGGW - elewacja zachodnia (opracowanie własne)

Fig. 4. Innovative Centre for Nutritional Sciences WULS-SGGW - western facade (own elaboration)

użytkowej czy celów technologicznych. Instalacja również może być wykorzystywana na cele związane z działalnością dydaktyczną i badawczą.

\section{Ukształtowanie wnętrza}

Zlokalizowana od strony południowej większa część budynku - część A - ma przy głównym wejściu powierzchnię przeznaczoną na szatnię. Proponuje się wykonać ją jako samoobsługową, sterowaną elektronicznie przez systemy komputerowe zarządzające instalacjami budynku. Biorąc pod uwagę ewentualność zwiększonego zapotrzebowania na powierzchnię szatniową (np. konferencja w zlokalizowanej na parterze sali konferencyjnej oraz równoczesne zajęcia dydaktyczne w trzech salach na pierwszym piętrze), może się okazać, że potrzebna jest $\mathrm{w}$ tym celu dodatkowa powierzchnia. W razie potrzeby proponuje się ją zlokalizować w podziemiu budynku.
Wewnętrzne patio części A ma wysokość czterech kondygnacji i jest przekryte górnym świetlikiem o konstrukcji aluminiowo-szklanej. Na parterze patio służy celom komunikacyjnym, recepcyjnym, ale także rekreacyjno-wypoczynkowym, np. dla uczestników konferencji czy sympozjów odbywających się w sali konferencyjnej (o wielkości wraz z zapleczem ok. $400 \mathrm{~m}^{2}$ i możliwości podziału składanymi ściankami systemowymi na dwie mniejsze części). $Z$ patio dostępny jest niewielki bufet oraz zespoły sanitariatów. Funkcjonalnymi i atrakcyjnymi elementami obudowanego szklanymi ścianami patio są dwie przeszklone, panoramiczne windy o napędzie hydraulicznym, łączące w pionie wszystkie wewnętrzne poziomy - wraz $\mathrm{z}$ wjazdem na poziom górnego stropodachu zielonego nad drugim piętrem budynku. Temu samemu celowi służą dostępne $\mathrm{z}$ patio dwie klatki schodowe. Wejścia do sąsiadujących z patio dwóch hal technologicznych 
(o powierzchni ok. $350 \mathrm{~m}^{2}$ każda) proponuje się oddzielić przestrzennie (i akustycznie) w pełni szklanym korytarzem wewnętrznym. Podobnie planuje się wydzielić powierzchnię bufetu - z możliwością rozsuwania szklanych ścian. W ten sposób wewnętrzne patio nabierze charakteru przeszklonego kryształu, z którego można zaglądać do poszczególnych poziomów, i rozświetlonego światłem słonecznym wpadającym przez szklane przekrycie. Przeszklenia otaczających patio galerii komunikacyjnych pełnią funkcje izolacji akustycznej, barier bezpieczeństwa i oddzieleń przeciwpożarowych, nie zatrzymując światła i wzroku. Podobnie wewnętrzne ściany dwóch dużych sal wykładowych (100 $\mathrm{m}^{2}$ każda) proponuje się wykonać od strony patio $\mathrm{w}$ technologii lustra weneckiego. Oczywiście do opisanych celów muszą być zastosowane odpowiednie rodzaje i zestawy szkła (bezpieczne, o odpowiedniej izolacyjności akustycznej i odporności ogniowej).

Poziom drugiego piętra połaczony jest $\mathrm{z}$ druga częścią budynku dwoma łącznikami. Jeden $\mathrm{z}$ nich to jedynie lekka przeszklona kładka, drugi to korytarz i ciąg laboratoriów. Obie części połączone są dodatkowo czwartą kondygnacją o przeznaczeniu technicznym. Połączenie obu części na wysokości ok. $8,5 \mathrm{~m}$ nad terenem gwarantuje, że przejedzie tędy każdy - nawet duży samochód (np. dźwig czy wóz straży pożarnej).

Część B obiektu jest częścią mniejszą, o dość prostym układzie korytarzowym. Prócz wewnętrznych klatek schodowych ma ona także dwie hydrauliczne windy osobowo-towarowe.

W obiekcie rozmieszczono bogaty program funkcjonalny na potrzeby badawcze i dydaktyczne. Obejmuje on przede wszystkim jedenaście laboratoriów o bardzo zróżnicowanych powierzchniach, dwie duże hale technologiczne, salę konferencyjną z zapleczem, sale wykładowe, pokoje biurowe, zaplecze sanitarne oraz pomieszczenia magazynowe i gospodarczotechniczne (tab. 1 i 2). Wszystko zostanie połączone powierzchniami i pionami komunikacyjnymi.

Zaproponowane $\mathrm{w}$ projekcie, zlokalizowane w piwnicy oraz na najwyższej kondygnacji technicznej, podziały powierzchni techniczno-gospodarczych

Tabela 1. Rozkład programu funkcjonalnego w budynku (opracowanie własne)

Table 1. Arrangement of the functional program in the building (own elaboration)

\begin{tabular}{|c|c|}
\hline $\begin{array}{l}\text { Kondygnacja budynku } \\
\text { Building floor }\end{array}$ & $\begin{array}{l}\text { Główne elementy programu funkcjonalnego } \\
\text { The main elements of the functional program }\end{array}$ \\
\hline $\begin{array}{l}\text { Parter } \\
\text { Ground floor }\end{array}$ & $\begin{array}{l}\text { Sala konferencyjna z zapleczem - Conference room } \\
\text { Hala technik i maszyn gastronomicznych - Hall of catering techniques and machines } \\
\text { Hala technologii przemysłu spożywczego - Food industry technology hall } \\
\text { Laboratorium innowacyjnych analiz technicznych - Innovative technical analysis } \\
\text { Laboratorium diagnostyki żywieniowej - Nutritional diagnostics laboratory } \\
\text { Laboratorium innowacyjnej gastronomii - Innovative gastronomy laboratory }\end{array}$ \\
\hline $\begin{array}{l}\text { Pierwsze piętro } \\
\text { First floor }\end{array}$ & $\begin{array}{l}\text { Laboratorium badań modelowych - Model research laboratory } \\
\text { Laboratorium techniki i projektowania żywności - Food technology and design laboratory } \\
\text { Sale wykładowe - Lecture halls } \\
\text { Pokoje pracownicze - Staff rooms }\end{array}$ \\
\hline $\begin{array}{l}\text { Drugie piętro } \\
\text { Secound floor }\end{array}$ & $\begin{array}{l}\text { Laboratorium nanotechnologii w żywieniu - Nanotechnology in nutrition laboratory } \\
\text { Laboratorium nutrigenomiki i biologii molekularnej - Nutrigenomics and molecular biology } \\
\text { laboratory } \\
\text { Laboratorium mikrobiologii żywności i mikrobiomu - Food microbiology and microbione } \\
\text { laboratory } \\
\text { Laboratorium badań sensorycznych i konsumenckich - Sensory and consumer research laboratory } \\
\text { Laboratorium edukacji żywieniowo-dietetycznej - Diet and nutrition education laboratory } \\
\text { Laboratorium żywności funkcjonalnej - Functional food laboratory }\end{array}$ \\
\hline
\end{tabular}


Tabela 2. Dane ogólne budynku (opracowanie własne)

Table 2. General building data (own elaboration)

\begin{tabular}{lc}
\hline Parametr - Parameter & Wielkość - Size \\
\hline $\begin{array}{l}\text { Powierzchnia użytkowa } \\
\text { Usable area }\end{array}$ & $7012 \mathrm{~m}^{2}$ \\
\hline $\begin{array}{l}\text { Powierzchnia całkowita } \\
\text { Total surface }\end{array}$ & $8106 \mathrm{~m}^{2}$ \\
\hline $\begin{array}{l}\text { Powierzchnia zabudowy } \\
\text { Building area }\end{array}$ & $4115 \mathrm{~m}^{2}$ \\
\hline $\begin{array}{l}\text { Kubatura } \\
\text { Volume }\end{array}$ & $37663 \mathrm{~m}^{3}$ \\
\hline
\end{tabular}

będą sprecyzowane przez zespół projektantów poszczególnych branż na etapie sporządzania projektu budowlanego centrum.

\section{Wyposażenie instalacyjne}

Zakłada się realizację budynku ,inteligentnego” - to znaczy maksymalnie wyposażonego $\mathrm{w}$ najnowsze rozwiązania techniczne $i$ technologiczne, sterowane i nadzorowane przez wewnętrzne systemy komputerowe.

Budynek podłączony będzie do zewnętrznych sieci technicznego uzbrojenia terenu (wodno-kanalizacyjnej, centralnego ogrzewania, gazowej, elektrycznej - wysoko i niskoprądowej), skłaniał się jednak będzie w swych rozwiązaniach do jak największej samowystarczalności - szczególnie energetycznej. Służyć ma temu wyposażenie obiektu w urządzenia do pozyskiwania energii elektrycznej i cieplnej $z$ energii słonecznej (ogniwa fotowoltaiczne, kolektory słoneczne). Zakłada się wyposażenie budynku $\mathrm{w}$ instalacje wentylacji mechanicznej i klimatyzacji $\mathrm{z}$ rekuperacją ciepła. Proponuje się zastosowanie systemów inteligentnych sterujących wentylacją i klimatyzacją obiektu strefowo, umożliwiając częściowe jej ograniczanie lub wyłączanie w przypadku np. otwarcia okien lub drzwi balkonowych w celu wyjścia na stropodach zielony.

Budynek wyposażony będzie w centralnie sterowane systemy nadzoru i monitorowania bezpieczeństwa w budynku - w tym także przeciwpożarowego.

Celem jak najbardziej ekonomicznego gospodarowania wodą, ściekami bytowymi i deszczowymi proponuje się stosowanie $\mathrm{np}$. do spłukiwania toalet nieszkodliwą wodę z procesów technologicznych lub gromadzoną wodę opadową. Celem minimalizacji ilości ścieków deszczowych proponuje się zastosowanie na zewnątrz zbiorników oraz biologicznie czynnych stropodachów bagiennych.

Szczegółowe decyzje dotyczące rozwiązań systemów instalacyjnych sformułowane będą przez zespół projektantów poszczególnych branż - na etapie sporządzania projektu budowlanego i projektów wykonawczych. Wtedy także będzie możliwe dokonanie podziałów i sprecyzowanie wielkości poszczególnych pomieszczeń techniczno-gospodarczych. $\mathrm{Na}$ etapie koncepcji zasugerowano ich umieszczenie $\mathrm{w}$ podziemiu oraz na trzecim piętrze - w kondygnacji technicznej. Połączeniu instalacji z obu części budynku służyć mają: podziemny kanał instalacyjny oraz strefy podpodłogowe i przestrzenie nad stropami podwieszonymi łączników drugiego piętra i najwyższej kondygnacji technicznej.

\section{Projektowane rozwiązania konstrukcyjno-materiałowe}

Projektuje się wykonanie obiektu w technologii szkieletu żelbetowego $\mathrm{z}$ użyciem wysokiej klasy materiałów izolacyjnych i wykończeniowych (zewnętrznych i wewnętrznych). Szklenie zestawami szkła zespolonego o możliwie minimalnym współczynniku $U$, które jest bezpieczne, z powłokami antyrefleksyjnymi i samoczyszczącymi. Wszystkie stosowane materiały powinny spełniać jak najwyższe wymagania techniczne. Wizualizację bryły centrum pokazano na rysunku 5 . 


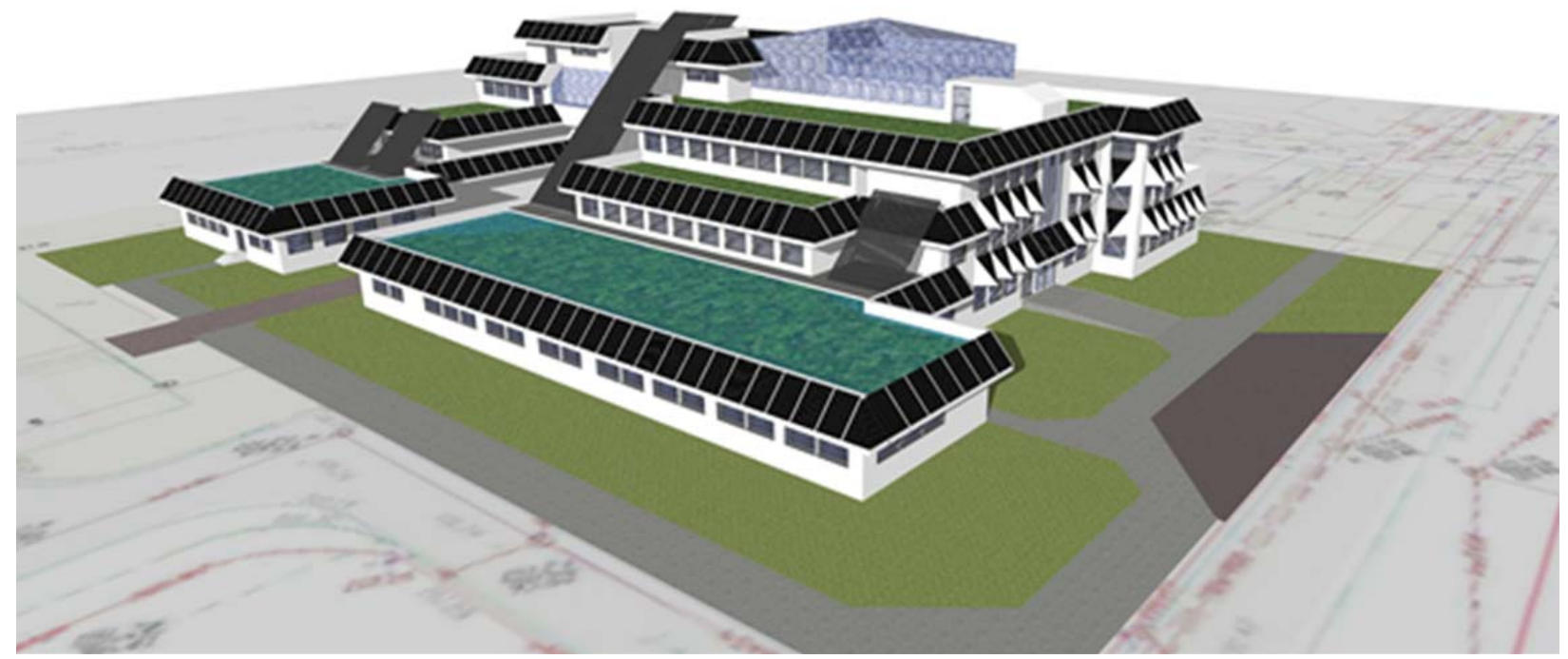

Rys. 5. Innowacyjne Centrum Nauk Żywieniowych SGGW - wizualizacja (opracowanie własne)

Fig. 5. Innovative Centre for Nutritional Sciences WULS-SGGW - visualization (own elaboration)

\section{Dostępność dla osób z niepełnosprawnościami - projektowanie uniwersalne - wygoda i bezpieczeństwo}

Koncepcja Innowacyjnego Centrum Nauk Żywieniowych SGGW sporządzona została przy założeniu poszanowania zasad ,projektowania uniwersalnego”. Ten typ projektowania polega na takim kształtowaniu obiektu, aby był on dostępny dla wszystkich użytkowników - także tych z niepełnosprawnościami. Należy pamiętać, że to nie tylko osoby poruszające się na wózkach inwalidzkich, ale także osoby np. niedowidzące czy niedosłyszące. Przy sporządzaniu dalszych etapów dokumentacji projektowej centrum (szczególnie projektu budowlanego) należy więc zwrócić uwagę na spełnienie wymogów projektowania uniwersalnego (projektowania dla wszystkich), poczynając od odpowiednich miejsc parkingowych, poprzez dostępność wejścia, odpowiednie gabaryty i właściwości elementów komunikacji wewnętrznej (drzwi, korytarzy, pochylni, dźwigów osobowych, eliminację progów, montaż uchwytów, przycisków, balustrad, antypoślizgowe posadzki itp.), odpowiednie zaprojektowanie toalet $\mathrm{i}$ stosowanie odpowiedniego systemu informacji i oznaczeń w budynku. Powinien on być możliwie prosty, czytelny i uniwersalny (piktogramy, alfabet Braille'a, pasy naprowadzające $\mathrm{z}$ zastosowaniem różnic faktury i barwy, odpowiednie, nieoślepia- jące oświetlenie). Przestrzeganie zasad projektowania uniwersalnego spowoduje, że obiekt będzie przyjazny dla wszystkich użytkowników. Poprawi ich wygode i bezpieczeństwo - także jeśli chodzi o ewentualna ewakuację w przypadku pożaru. Koncepcja ICNŻ SGGW zakłada pełne przestrzeganie obowiązujących przepisów oraz norm dotyczących ochrony i bezpieczeństwa pożarowego. Polskie przepisy nie zawierają szczegółowych uregulowań dotyczących rozwiązań funkcjonalno-przestrzennych i technicznych, które pozwoliłyby na w pełni sprawną i bezpieczną ewakuację osób z niepełnosprawnościami. Tym ważniejsze staje się projektowanie uniwersalne.

\section{PODSUMOWANIE}

Innowacyjne Centrum Nauk Żywieniowych SGGW będzie wielofunkcyjnym obiektem, który bardzo wzbogaci ofertę naukowo-dydaktyczną uczelni. Jego innowacyjność to nie tylko rodzaj, poziom i różnorodność badań naukowych jedenastu laboratoriów oraz formy i zakres prowadzonej przez centrum działalności dydaktyczno-edukacyjnej, ale też jego techniczny i technologiczny ksztalt, „ekologiczność” i poszanowanie dla środowiska przyrodniczego, zaproponowanych w nim rozwiązań funkcjonalno-przestrzennych, materiałowo-konstrukcyjnych i instalacyjnych. Stwo- 
rzone przy zastosowaniu zasad projektowania uniwersalnego będzie miejscem przyjaznym wszystkim przyszłym użytkownikom, gwarantując im wygodę, bezpieczeństwo oraz komfortowe warunki do pracy i nauki. Dobrze zaprojektowane centrum będzie służyło nie tylko rozwojowi nauki i dydaktyki w zakresie żywienia, ale też może być wykorzystane jako obiekt doświadczalny przez inne jednostki nauki, np. w zakresie gospodarowania woda czy optymalizowania obiektu w zakresie zaopatrywania w odnawialne źródła energii.

\section{PIŚMIENNICTWO}

Boratyńska, K. i Huseynov, R. T. (2017). An innovative approach to food security policy in developing countries. Journal of Innovation \& Knowledge, 2, 39-44. https:// doi.org/10.1016/j.jik.2016.01.007
Glover, D. i Poole, N. (2019). Principles of innovation to build nutrition-sensitive food systems in South Asia. Food Policy, 82, 63-73. https://doi.org/10.1016/j. foodpol.2018.10.010

Lewis, K. D. i Burton-Freeman, B. M. (2010). The role of innovation and technology in meeting individual nutritional needs. The Journal of Nutrition, 140, 426-436. https://doi.org/10.3945/jn.109.114710

Savino, T., Testa, S. i Messeni Petruzzelli, A. (2018). Researcher understanding of food innovations in Nordic and Southern European countries: A systematic literature review. Trends in Food Science \& Technology, 77, 54-63. https://doi.org/10.1016/j.tifs.2018.05.008

Shilomboleni, H. i De Plaen, R. (2019). Scaling up research for development innovations in the food and agriculture systems. Development in Practice, 29 (6), 723-734. https://doi.org/10.1080/09614524.2019.1590531

\title{
FUNCTIONAL AND SPATIAL ARCHITECTURAL CONCEPT OF THE INNOVATIVE CENTRE FOR NUTRITIONAL SCIENCES OF THE WARSAW UNIVERSITY OF LIFE SCIENCES - SGGW
}

\begin{abstract}
The need to improve and develop the teaching and scientific base in the field of nutritional sciences is one of the priorities of the European Union and Poland. The article presents the genesis of the creation of the Innovative Centre for Nutritional Sciences of the Warsaw University of Life Sciences - SGGW, together with the formal, legal, functional, spatial, material and construction foundations of its architectural concept. Development of such scientific and teaching centres reflects global trend observed in development of nutrition sciences worldwide.
\end{abstract}

Key words: design, innovation, science, nutrition 